\title{
A Deictic Analysis of Pakistan's National Identity Representation in the Indigenous English Newspapers
}

\author{
Faiqa A. Khaliq ${ }^{1} \&$ María Isabel Maldonado García ${ }^{1}$ \\ ${ }^{1}$ Department of English Language and Literature, University of Management and Technology, Lahore, Pakistan \\ Correspondence: Faiqa Abdul Khaliq, Department of English Language and Literature, University of \\ Management and Technology, Lahore, Pakistan. E-mail: faiqa_khaliq@yahoo.com
}

$\begin{array}{ll}\text { Received: December 17, } 2018 & \text { Accepted: January 10, } 2019 \text { Online Published: March 2, } 2019 \\ \text { doi:10.5539/ijel.v9n2p307 } & \text { URL: https://doi.org/10.5539/ijel.v9n2p307 }\end{array}$

\begin{abstract}
The goal set for the present study is to investigate the temporal and spatial deixis which are used to represent and build the national identity of Pakistan in the two leading indigenous English newspapers. The study investigates how the WAR and NATION frames are used in the opinion articles of The News and DAWN to project the negative image of Pakistan by using temporal and spatial deixis. The data collection is based on the ten years of opinion articles from 2007-2017. The political situation of Pakistan in the year 2007 was crucial and it is marked as a step towards the revival of civilian democracy through the announcement of general election in Pakistan during the ongoing war on terror. Purposive sampling technique is used in the selection of data. The theoretical foundation is based on the Anderson's (1991) Imagined community. The empirical framework is based on Harts' (2014) Critical Cognitive Discourse Analysis. Both qualitative and quantitative methods are employed. Antconc is used to generate the frequencies and concordance lines of the text. The data analysis shows that journalists mostly projected the negative image of Pakistan by utilizing different deixis and by linking the events of past from shared memories with the present and the future events by conceptualizing WAR and NATION Frames.
\end{abstract}

Keywords: Cognitive Linguistics, imagined communities, national identity of Pakistan, critical cognitive discourse analysis, temporal and spatial deixis, the print media of Pakistan

\section{Introduction}

\subsection{National Identity}

The idea of 'nation' and 'national identity' dates back to antiquity. The term national identity is generally related with nationalism (Anderson, 1991). However, Gellner (1965) claims that nationalism only works when the nation is passing through any crisis and nationals are unacquainted with that crisis. Masses, which are aware do not follow any nationalist agenda. The national identity is the representation of people which is articulated by the nationals. Butler (1999) declares national identity to be the choice and the option of nationals in case if they like to associate themselves with a certain political community. Smith (1991) attempts to present a comprehensive definition of national identity but later proposed changes. He postulates five characteristics a nation must possess. These are: it has to be a political community; historically connected; political community must share common values; culture and bounded by shared customs and traditions; the relationship of community members with their territory must be from time immemorial and common shared past (ibid. p. 9). Political community should be expressive about their national sentiments. The idea of national identity can be applicable only to the nationals of the sovereign states and which are connected by common language, history, educational programmes, and a representative mass media. Anderson (1991) presented a classic and compact definition of national identity. He proposes that a nation is an imagined political community; limited in terms of its borders, and enjoys the status of a sovereign power. According to him, a vernacular links the political community. He emphasized on the "the role of print media' as a key power house which spread the sentiments of nationalism amongst the nationals. Smith (1991) maintains that nationalism is used by the political elites to impact the nationals and leads towards a certain direction. He endorsed Anderson's idea of religious nationalism and claims that religious nationalism is gaining momentum in Israel with the revival of Hebrew and with the promotion of Judaism while in countries like Pakistan and Malaysia Islamic nationalism is also being promoted (ibid, p. 141). With the projection of religious nationalism, a new form of religious extremism is being represented as the new national identity. Guibernau (2004) adds in this connection that many nations in the world have more than indigenous languages 
i.e., Canada and Belgium and there are nations in the world who replaced their indigenous language as happened in Scotland. The tragedy of 9/11 initiated the change of discourse in the world politics and brings the world to discuss the importance of national identities of the states. This brings the shift of discourse from globalization to national identity discourse. The linguistic situation in post-colonial sovereign states also differs from the colonizers as they have different official and indigenous languages i.e. the multi ethnic societies of Pakistan and India where English is the official, language of higher education and of judiciary and lingua franca of the masses. Many national dailies and weekly newspapers are published in English language in Pakistan.

\subsubsection{The Importance of Print Media and Language}

Anderson (1991) puts forward that national identity is not something people inherit in their blood, rather it is build and constructed by the print media. The construction and representation of national identity is bounded with the social fabric of the nation or state and the print media by employing a vernacular language which serves as a connector between people of a community and their imagination of community. Thomson (1995, p. 35) declares that media plays a substantial role in the creation of imagined communities and the people associate themselves with their nation by conceptualizing. Print media raise the issues related to national identity. National identity changes with the changes in the social, strategic and economic conditions of the nation. The representation of past events which are shared by people and which remain as a shared memory is represented in the print media by using symbolic and metaphorical images. In this way, the print media maintains the institutional hegemony. Journalists and writers' personal opinions and ideologies also influence the representation of national identity discourse. The manufactured news is presented after careful selection of lexical and grammatical structures (Fowler, 1991). Herman and Chomsky (1988) presented a propaganda model which outlines that the media power houses create propaganda to achieve financial benefits by portraying their hidden agendas. Propaganda creates an instant risk to the reader. Facts are manipulated. The language used in the propaganda discourse about national identity is carefully selected and it intensifies the whole situation by presenting the nationals as the victims. According to Anderson (1991), the role of language is pivotal as it connects the people of the community to their shared culture and past memories.

\subsubsection{English Print Media in Pakistan}

Many daily newspapers in English language are published in Pakistan. The present study is based on the corpus of two leading English newspapers in Pakistan. DAWN is Pakistan's leading liberal English newspaper published by Herald. The Herald group is a conglomerate holding both electronic and print media channels named as DAWN News. This newspaper was inaugurated by the founder of Pakistan, Quaid-i-Azam in 1941 before partition of the sub-continent.

The News is the second most read English newspaper in Pakistan. This newspaper also holds electronic channels named GEO News and like DAWN, is an influential newspaper. The News group media owns 'Jang', the largest circulating newspaper in Urdu language in Pakistan. In both newspapers many prominent writers write opinion articles and columns. These opinion articles present the positioning of the writers about their stance on certain crucial issues. For the present study, 15 opinion articles are selected from both the newspapers related to national identity of Pakistan.

\subsection{Pakistan's Turmoil as a Nation State}

Since the creation of Pakistan as a nation state and its independence from the colonial sub-continent in 1947, Pakistan has faced catastrophic ideological tragedies, three massive wars with India and a prolonged war on terror after 9/11. Political and constitutional chaos in the country resulted in three martial laws which were a decade long. Ideological turmoil resulted in the separation and creation of Bangladesh in 1971 and the two-nation theory was then nullified as a result. Pakistan entered in the war of terror of the USA in Afghanistan and as a result faced endless terror attacks and killings in the state. 2007 brought another calamity in Pakistan. The return of the ex- Prime Minister Benazir Bhutto after signing National Reconciliation Ordinance (NRO) with the, then, President General Musharraf and her assassination brought a new wave of political awareness, followed by general elections in 2008 in the country. The restoration of democracy in Pakistan was welcomed by everyone. On the contrary, the democratic era starting from 2008 brought with it some extremely difficult situations in the country. The sovereignty of Pakistan was challenged due to the extremism and the repercussions of war on terror. The critical discourse about Pakistan's national identity in the indigenous English print media was represented in a negative manner. Representation is about the community, its integrity and sovereignty. The present study explores the linguistic devices which are used to connect the events of past and link it with the national identity of Pakistan. 


\subsection{Critical Cognitive Discourse Analysis}

During the last decade of the 20th century, a group of researchers and analysts, including Wodak, VanDijk, Fairclough, Mayers and Scollan came together and formulated the mechanism to set parameters for Critical Discourse Analysis. The field of CDA developed as an approach with its own methodology and theoretical designs. It should not be seen as a method only. CDA researchers, including Wodak, VanDijk, and Fairclough use the terms like "hegemony", "ideology," "gender," "power abuse," "inequality" in text and speech. Research in CDA studies has given a new direction to the fields of gender, race, media, feminism and religious discourse. VanDijk (2008) adds that CDA is a multidisciplinary field. Weiss and Wodak (2003) add in this connection that CDA attempts to study manifold subjects which are originated from diverse fields, it takes multiple epistemological and conceptual frameworks; work with multiple types of data and device new methods and experiment new techniques to test the hypotheses (p. 12).

Hart $(2010,2014)$ introduced an innovative synergy in the field of critical discourse studies i.e., critical cognitive turn in the discourse analysis. This theory presented in the domain of Cognitive Linguistics. Langacker (2008) puts forward that in Cognitive Linguistics, grammar associates itself not just with the structure but with the meanings and with the symbolic representations of linguistic patterns. Hart (2010) figures out that ideology manifestation in the discourse is carried out with the help of repeated linguistic variables or construals for a particular context. These variables carry meanings and are used multiple times by the speakers and the writers to portray a certain ideology. Ideologies are conveyed through the use of metaphors, models, deixis, and schematization. He divided the linguistic and psychological concepts into four altered types of cognitive processes and linguistic strategies which employ construals of different categories to represent discourse. Hart (2014) presents CCDA model to study the immigrant discourse in UK. And his empirical framework is based on many theoretical frameworks. Hart's CCDA model is equally applicable to national identity discourse as well.

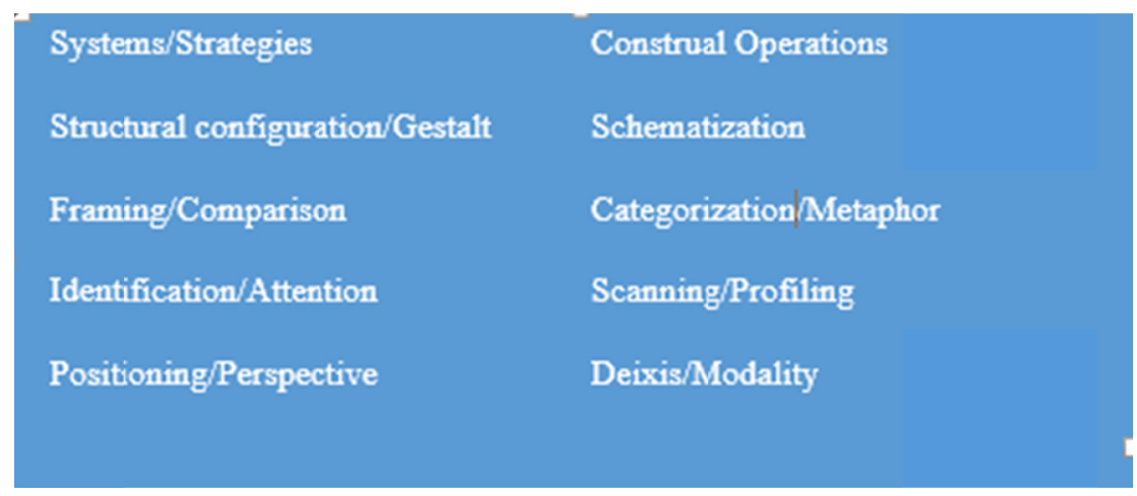

Figure 1. Hart (2014, p. 111) CCDA

The construal operations can be studied with interchangeable systems and strategies with multiple construal operations. This adds in the validity and variation of the model. In this study, the focus of national identity discourse of Pakistan is on the representation of two Frames NATION and WAR with reference to the deictic positioning in the opinion articles.

\subsubsection{Deixis and Discourse Space Theory}

The word 'deixis' has its origin in the Greek language which means 'to indicate or 'to point out' towards something or actions. Deixis, as being discursive devices, develop the link between past events and present events by making the utterances more meaningful and explicit for the readers and the listeners. According to Crystal (2003), deixis are linguistic categories which point out towards the time, place and person in the stretch of an utterance or in discourse. Deixis provides a connection between the past contexts of events with the present situation. Hanks (1992) endorsed the idea of deixis as the linguistic categories which links the past with the present. According to Yule (1996) context can be referred by three different linguistic categories: symbolic measures, by using gestures and with the help of anaphoric reference by employing deixis. Huang (2007) identified four different types of deixis including place, time, demonstratives and personal pronouns. Hart (2014) elaborate the conceptualization of deixis in terms of temporal (now/then), spatial deixis (here/there; us/them) and epistemic (right/wrong).

Hart (2014) adopted the Discourse Space Theory (DST) which was presented by Chilton (2004) and the 
theoretical development of DST was further expended by Cap (2006). The temporal and spatial deixis used in a particular context represent the conceptualization perceived by the speaker and the writers. The speaker or writer opens a mental space and the subject or problem is conceptually presented on three different categories of deixis, representing on axis of time, space and evaluation intersecting on the deictic center. Cap (2006) adds that certain strategy or position is adopted by the speaker to express his perspective by linking the past events with the present and future events. This strategy is adopted to present the ideology related to the positioning of speaker. Hart (2014) does not only focus on the deictic at pronoun level rather extends it to noun phrase, prepositional phrases and verb phrases. Noun phrases are conceptualized as protagonist and antagonist. Verb phrases are conceptualized as the actions taken by antagonists. Prepositional phrases are conceptualized in terms of action towards protagonists. Tense also plays an important role to determine the meanings of conceptualization through temporal and spatial deixis.

\subsubsection{Proximization Strategy through Deixis}

In this study, the sentences from opinion articles are analyzed within the reference of Proximization. In the Proximization strategy, the vectors connect the events and movements that happened in the past and are linked with the present (Hart, 2010). The writers conceptualised the events through phraseological proximization (complete contextual information is conceptualised in one sentence) or narrative proximization (incomplete conceptualization by the writer). The present study focuses on the proximization strategy in DST as it predicts about the shared memories related to events from 2007-2017 in Pakistan.

\subsubsection{Frames}

In the present study, two frames NATION and WAR are investigated with reference to deictic analysis. Frames are the knowledge-based structures which project different evaluative and experiential characteristic formation through the process of conceptualization (Hart, 2014, p. 111). Frames are related to information process and the perception of information by comparison. Frames are the representations of related ideas in thought manifested through language (Druckman, 2001). Frames are the representation of real incidents happened in the past and present, executed by agents and are perceived by the people in the related senses. Frames are based on the process of comparison and categorization (Hart, 2014). Another way to conceptualize the frames is by using the metaphorical and symbolic representation.

$>$ NATION frame is related to the political community of Pakistan. NATION frame is related to the work of state, governments, country and especially the conceptualization of 'Pakistan as a political community' by the writers.

D WAR frame is related to the sovereignty of the political community. The political community is limited to its borders and only the internal matters are analyzed in the present research. The use of WAR frame in the opinion articles shows the perception of the writer and his or her positioning about the sovereignty of Pakistan.

The conceptual and methodological framework designed for the present study is shown in Figure 2.
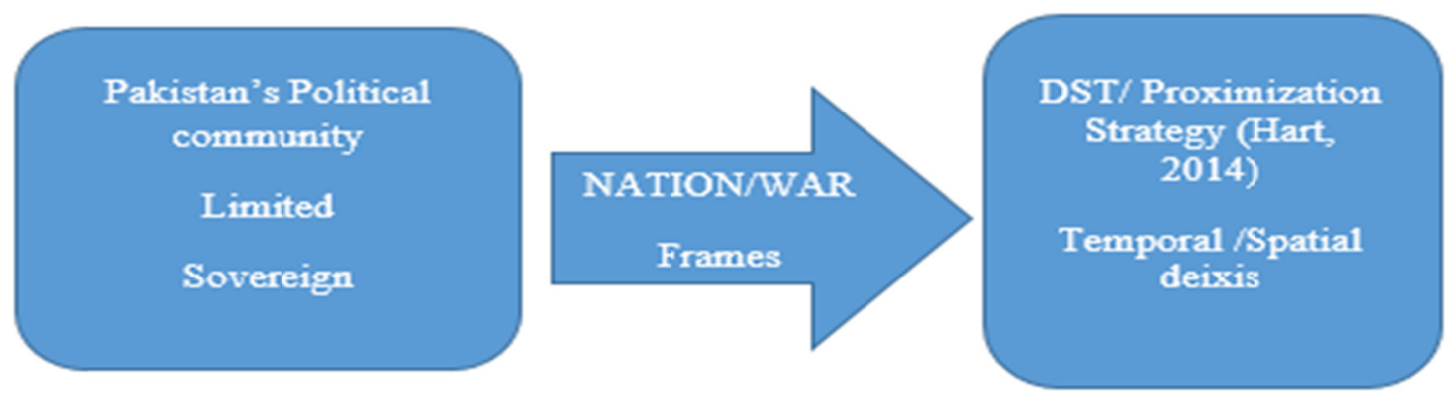

Figure 2. Conceptual and methodological framework

The Figure 2 shows the conceptual framework of the study which is derived from Anderson's definition of nation which is about the representation of Pakistan as a political community with its marked boundaries and 
sovereignty, is represented through the war going on in the state of Pakistan. The empirical framework is derived from the proximization strategy discussed by Discourse Theory (Hart, 2014). Proximization strategy is discussed in terms of deixis of person and time with direct reference to pronouns and extended phrases.

\section{Research Questions}

The present study is designed to find out the answers of the following research questions:

1) How are the temporal and spatial deixis used in the opinion articles to represent the national identity of Pakistan in terms of NATION and WAR frame?

2) What sort of role does the temporal and spatial deixis play in the meaning construction of the national identity of Pakistan in terms of WAR and NATION frame?

\section{Methodology and Data Collection}

To find the answers of the research questions, the present study is designed both qualitatively and quantitatively as well. A mixed method approach authenticates the results and findings of the research. The corpus of 15 texts was compiled from two leading English newspapers DAWN and The News. McEnery and Wilson (1996, p. 177) define Corpus Linguistics as the branch of linguistics which uses computational techniques to study maximally representative text of a language. Baker (2006) elaborates different aspects of the corpus study. According to him, corpus is manipulated in terms of types/tokens, concordance lines, frequency etc. Tokens are the total words in a corpus while types are occurrence of same token in the corpus. Frequency is the number of occurrence of tokens in a corpus. The focus of the data collection was the opinion articles. The data were collected from the online versions of both newspapers. Opinion articles of renowned writers were included. A purposive sampling technique was used to collect the data as the focus was on the discourse which is created about the national identity of Pakistan. All the articles were read thoroughly and the overall meanings of the texts were determined. In the first step, all the data were converted into word files from pdf files and the names and dates and images were removed. Only text was left for data processing. In the second step, the word file was converted into text file on notepad. Antconc 3.5.7 version was used for corpus processing. Antconc is a reliable software package for data mining and it provides many options for data processing including the generation of word frequency lists, concordance lines, collocation, comparison of word lists etc. In this study,

$>$ First, the word frequency list of the text of opinion articles was generated.

$>$ The second step was to find the frequencies of the tokens including Pakistan, War, Nation and pronouns (I, you, we, and they) and temporal deixis (now, then).

$>$ The third step was to generate the concordance lines of the words related to WAR and NATION frames. Concordance lines present the preceding and following words in the particular context (Baker, 2006).

$>$ The fourth stage was to analyze both the frames within the DST model presented by Hart (2014). For this, spatial and temporal deixis along with noun phrases, verb phrases and prepositional phrases were analyzed and discussed according to three-dimensional model of DST (Hart, 2014).

\section{Delimitations}

> The study is restricted to 15 opinion articles from 2007-2017 and only temporal and spatial deixis in terms of WAR and NATION frame are studied according to DST model (Hart, 2014). The epistemic aspect of the theory is not added, which can be studied in further research. The model can be implemented on a wide range of data including the spoken corpus of electronic media.

\section{Data Analysis and Discussion}

The data analysis of 15 opinion articles (List: Appendix A) shows the total token were 17,429 and the total types were 4,119. Appendix B shows the screen shot of Antconc which displays the types/tokens and the frequency of the word Pakistan. Pakistan represents the 'imagined community'. Pakistan as the nation, is the landmark related to place, where all the actions have taken place, so it is counted in the spatial deixis. The use of Pakistan as a highly occurring content word in 15 opinion articles shows that the writers have directly refered to Pakistan. In the corpus of 17,429 tokens, the raw frequency of type 'Pakistan' is 112 (Appendix B) and has a normalized frequency 64.26 times. The normalized frequency in this paper is measured on the bases of ten thousand words as it is a small sized corpus. 
Table 1. Frequency of the token 'Pakistan'

\begin{tabular}{llll}
\hline No & Token & Frequency of occurrence & Normalized frequency* \\
\hline 1. & Total & 17429 & - \\
2. & Pakistan & 112 & 64.26 \\
\hline
\end{tabular}

Note. ${ }^{*}$ Normalized frequency $=10,000$.

The type Pakistan represents the deixis of place. In this case the writers provide opinions about the state of Pakistan. The high frequency of occurrence shows that the writers have opened the mental space about Pakistan and link it with the events which are taking place inside and about Pakistan.

\subsection{Nation and War Frame in DST}

The corpus analysis in Table 2 shows the frequency of occurrence of Nation and War in 15 texts of opinion articles.

Table 2. Frequency of War and Nation

\begin{tabular}{llll}
\hline No. & Words & Frequency of occurrence & Normalized frequency* \\
\hline 1. & War & 27 & 15.5 \\
2. & Nation & 21 & 12.05 \\
\hline
\end{tabular}

Note. ${ }^{*}$ Normalized frequency $=10,000$.

The raw frequency of War is 27 and the normalized is 15.5 whereas the raw frequency of Nation is 21 and the normalized is 12.05 .

\subsubsection{War}

The concordance lines in Figure 3 show the occurrence of word 'war' in the text. The concordance lines of the War frame in Figure 3 shows the occurrence of type war in the text. These lines are generated by adding text file in Antconc like this (as shown in figure 3):

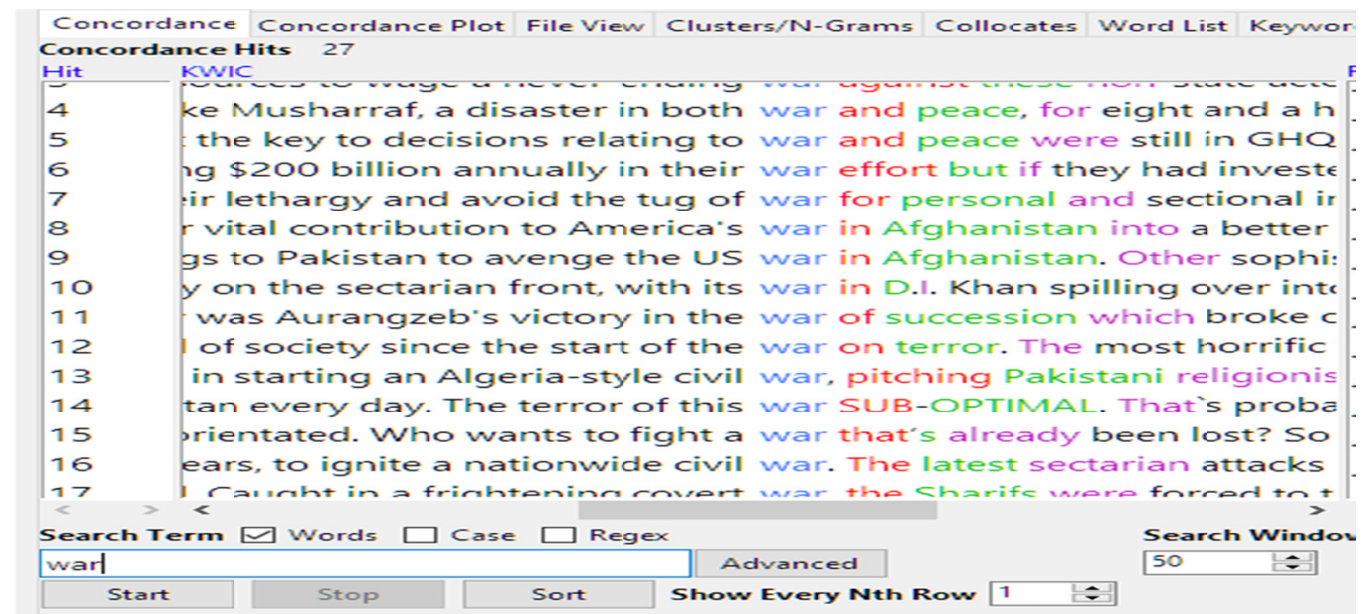

Figure 3. Concordance lines of War

The data in Table 3 shows the representation of War in the text of opinion articles. The detailed analysis shows that the War frame has invoked a negative representation of Pakistan. The writers of opinion articles have unlocked the deictic centers as there is a threat to the protagonist by the antagonists. The Proximization strategy relates the events with the protagonists and antagonists. In DST: extended deixis is employed to construct the reality. Noun Phrases are presented as Protagonists; Action is represented through VP carried by Antagonist; Noun phrase represented as Antagonist; vectors connect past events with the present events. Antagonists are the powerful ones; Protagonists are the ones who suffer because of Antagonists. 
Table 3. Data analysis: War

\begin{tabular}{|c|c|}
\hline No. Text & Analysis (DST) \\
\hline $\begin{array}{l}\text { 1. Terrorists, with } \\
\text { all-out cross-border } \\
\text { assistance, have thus far } \\
\text { killed some } 70,000 \\
\text { people and paralyzed all } \\
\text { of society since the start } \\
\text { of the war on terror. The } \\
\text { News. January } 25 \text {, } \\
2016 \text {. }\end{array}$ & $\begin{array}{l}\text { Temporal Proximization } \\
=\text { Deictic center } \mathrm{T}=\text { year } 2016, \\
\text { Action past } \mathrm{Tp}=\text { start } \\
\mathrm{T}=\text { =thus } \\
\text { Vector=connecting Tp with } \mathrm{T} \\
\text { Spatial Proximization = } \\
\text { Antagonists = NP=Terrorists/threat to protagonist; cross border } \\
\text { Action of Antagonist = killed/past event } \\
\text { Protagonists = people } \\
\text { Action = paralyzed/ past } \\
\mathrm{TP}=\text { since } \\
\text { Protagonist = all of society } \\
\mathrm{S}=\text { war on terror. } \\
\text { The text shows phraseological proximization in which the Antagonists are connected by vectors shows as a } \\
\text { means of threat to the Antagonist. This process of discourse representation is completed in one single } \\
\text { stretch of sentence. This text is an example of phraseological proximization as the threat is completely } \\
\text { obvious and invoked by the writer within the context. }\end{array}$ \\
\hline $\begin{array}{l}\text { 2. What was the ISI, or } \\
\text { rather the army, trying } \\
\text { to prove? That the key } \\
\text { to decisions relating to } \\
\text { war and peace were still } \\
\text { in GHQ. The News. } \\
\text { March } 14,2011 .\end{array}$ & $\begin{array}{l}\text { Temporal Proximization= } \\
\mathrm{T}=2011 / \text { still } \\
\mathrm{TP}=\text { ware } \\
\text { Spatial Proximization= } \\
\text { Action }=\mathrm{VP}=\text { trying/continued } \\
\text { Antagonist }=\mathrm{NP}=\mathrm{ISI} \text {, army } \\
\text { Protagonist }=\text { not obvious } \\
\text { This type of sentence is narrative proximization as the context is not clear in a stretch of sentence and } \\
\text { obvious Protagonist is missing. Threat from Antagonist is not clearly targeted. }\end{array}$ \\
\hline $\begin{array}{l}\text { 3. That Mr Mehsud had } \\
\text { declared war upon the } \\
\text { Pakistani state and } \\
\text { personally decapitated } \\
\text { Pakistani soldiers } \\
\text { mattered to neither. } \\
\text { DAWN September } 27 \text {, } \\
\text { 2014. }\end{array}$ & $\begin{array}{l}\text { Spatial Proximzation }= \\
\text { Antagonist }=\mathrm{NP}=\mathrm{Mr} \text {. Mehsud } \\
\text { Protagonist }=\mathrm{NP}=\text { Pakistani state; Pakistani soldiers, } \\
\text { Action=VP/had declared/past; decapitated } \\
\text { Temporal Proximization= } \\
\mathrm{T}=2014 \\
\mathrm{Tp}=\text { Past perfect } \\
\text { Example of narrative proximization, action happened in the past. }\end{array}$ \\
\hline $\begin{array}{l}\text { 4. The basic mistake: } \\
\text { we're not at war with } \\
\text { the Taliban; we're at } \\
\text { war with ourselves. } \\
\text { DAWN January 12, } \\
2014 \text {. }\end{array}$ & $\begin{array}{l}\text { Spatial Prozimization }= \\
\text { Protagonist }=\mathrm{NP}=\mathrm{We} \\
\text { Antagonist }=\mathrm{Taliban} \text {, ourselves } \\
\text { Action =at war } \\
\text { Temporal Proximization }=\mathrm{T}=2014 \\
\text { Vectors are not connecting } \mathrm{t} \text { with } \mathrm{TP} . \\
\text { Tense is present indefinite. } \\
\text { Narrative Proximization is invoked in the sentence as the context is not clear. }\end{array}$ \\
\hline $\begin{array}{l}\text { 5. The Lashkar } \\
\text { effectively introduced } \\
\text { suicide bombings to } \\
\text { Pakistan to avenge the } \\
\text { US war in Afghanistan. } \\
\text { DAWN October 15, } \\
2008 \text {. }\end{array}$ & $\begin{array}{l}\text { Spatial Proximization }= \\
\text { Antagonist }=\mathrm{NP}=\text { Lashkar, suicide bombings } / \text { US War } \\
\text { Protagonist }=\text { Pakistan, Afghanistan } \\
\text { Action }=\mathrm{VP}=\text { introduced/past tense } \\
\text { Temporal Proximization }= \\
\mathrm{T}=2008 \\
\text { Narrative Proximization } \\
\text { The contextual information is not properly invoked in one sentence. Vectors are not connecting T with TP }\end{array}$ \\
\hline $\begin{array}{l}\text { 6. We concluded our } \\
\text { first military agreement } \\
\text { with the US in } 1951 . \\
\text { Sixty odd years later we } \\
\text { remain locked in } \\
\text { America's military } \\
\text { embrace, fighting a war } \\
\text { whose direction and } \\
\text { purpose are defined by } \\
\text { the US. The News } \\
\text { October } 1,2010 \text {. }\end{array}$ & $\begin{array}{l}\text { Spatial Proximization } \\
\text { Protagonist }=\mathrm{NP}=\mathrm{We} \\
\text { Antagonist }=\mathrm{NP}=\mathrm{US} \\
\text { Action }=\text { concluded/past } \\
\text { Temporal Proximization } \\
\text { Protagonist }=\mathrm{NP}=\mathrm{We} \\
\text { Antagonist }=\mathrm{NP}=\text { America's military } \\
\text { Action }=\text { locked/past } \\
\mathrm{T}=2010 \\
\mathrm{Tp}=1951,60 \text { years later } \\
\text { The text is representing Phraseological Proximization as the threat from antagonist for protagonist is clear } \\
\text { in the stretch of sentences. }\end{array}$ \\
\hline
\end{tabular}




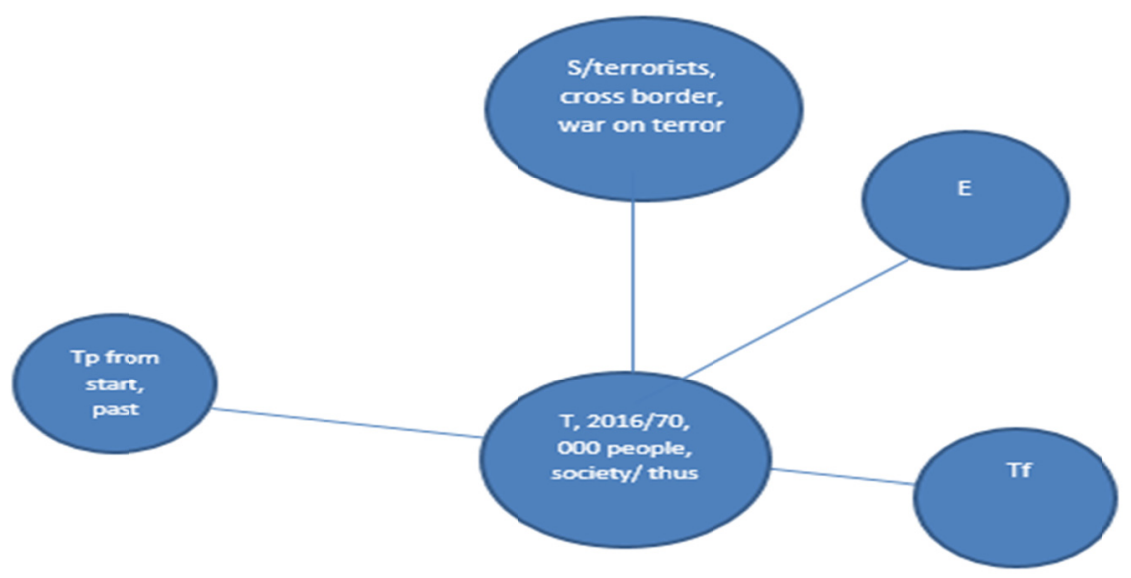

Figure 4. Deictic representation of War on DST model

$\mathrm{Tp}=$ Time past; $\mathrm{T}=$ Now, 2016, 70,000; Tf=Time future; $\mathrm{S}=$ Spatial; terrorists, war; $\mathrm{E}=$ =Epistemic (impact). The textual analysis in Table 3 shows that the WAR frame was invoked as a negative representation of Pakistan's national identity. Figure 4 shows the textual representation of Text $\# 1$ in table 2 . The vectors are connecting the temporal and spatial axes at the deictic center. The writer opens the mental discourse by placing society, 70,000 people killed at the center whereas the Tp shows the event structure has started in the past and continued till present. Other sentences in Table 2 also show the representation of national identity of Pakistan in terms of temporal and spatial deixis in terms of War frame. The Next analysis is of Nation frame.

\subsubsection{Nation Frame}

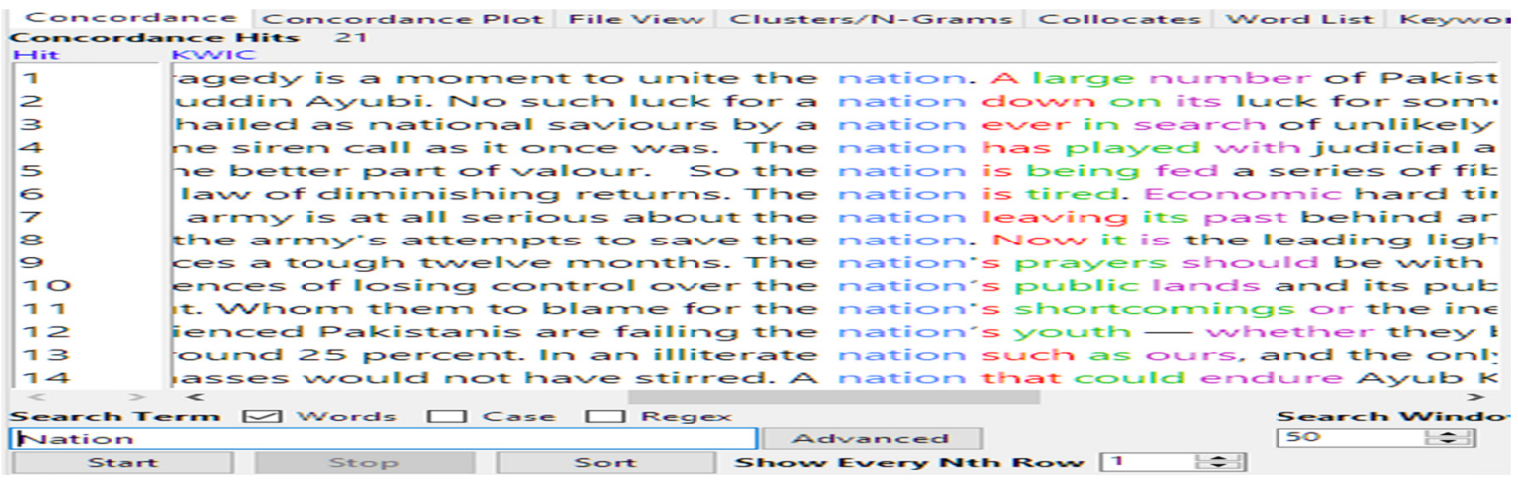

Figure 5. Concordance lines of Nation

Figure 5 shows the concordance lines of the word Nation which occurs in the 15 opinion texts. 
Table 4. Data analysis: Nation

\begin{tabular}{|c|c|}
\hline No. Text & Analysis (DST) \\
\hline $\begin{array}{l}\text { 1. Pakistan's leaders must soberly } \\
\text { consider the consequences of } \\
\text { losing control over the nation's } \\
\text { public lands and its public assets. } \\
\text { DAWN December 24, } 2016\end{array}$ & $\begin{array}{l}\text { Spatial Proximization } \\
\text { Protagonist=Np=Nation's public lands /public asserts } \\
\text { Antagonist=Pakistan's' leaders } \\
\text { Action=VP= must soberly consider } \\
\text { Temporal Proximization } \\
\mathrm{T}=2016 \\
\text { Narrative Proximization is invoked as Tp is not invoked }\end{array}$ \\
\hline $\begin{array}{l}\text { 2. The nation is tired. Economic } \\
\text { hard times, the perpetual } \\
\text { loadshedding, seem more pressing } \\
\text { issues than arguments about the } \\
\text { rule of law. The News. August } 10 \text {, } \\
2010 \text { August } 10,2012\end{array}$ & $\begin{array}{l}\text { Spatial Proximization } \\
\text { Protagonist }=\text { Nation } \\
\text { Action=Tired } \\
\text { Whole Pakistani community is suffering. } \\
\text { Antagonists=Np= loadshedding (power failure), economic hard times, } \\
\text { Temporal Proximization } \\
\mathrm{T}=2012 \text {, perpetual } \\
\text { Narrative Proximization is invoked in this sentence. }\end{array}$ \\
\hline $\begin{array}{l}\text { 3. A strange nation we are, } \\
\text { expecting wisdom from morons, } \\
\text { radicalism from born } \\
\text { opportunists, and virtue from } \\
\text { knaves whose principal claim to } \\
\text { fame is daylight national } \\
\text { robbery. The News. May, } 30,2008\end{array}$ & $\begin{array}{l}\text { Spatial Proximization } \\
\text { Protagonists }=\mathrm{NP}=\text { strange nation } \\
\text { Antagonists }=\mathrm{NP}=\text { born opportunists, morons, knaves } \\
\text { Action=expecting, national robbery } \\
\text { Temporal Proximization } \\
\mathrm{T}=2008 \text {, daylight } \\
\text { Narrative Proximization is invoked in this sentence. }\end{array}$ \\
\hline $\begin{array}{l}\text { 4. Experienced Pakistanis are } \\
\text { failing the nation's } \\
\text { youth-whether they be hapless } \\
\text { students or newly appointed } \\
\text { foreign ministers. DAWN. July } \\
25,2011\end{array}$ & $\begin{array}{l}\text { Spatial Proximization } \\
\text { Protagonists }=\mathrm{Np}=\text { nation's youth, students, foreign minister } \\
\text { Antagonists }=\mathrm{Np}=\text { experienced Pakistanis } \\
\text { Action }=\mathrm{VP}=\text { failing } \\
\text { Temporal Proximization } \\
\mathrm{T}=2011 \text { /continuous tense } \\
\text { Narrative Proximization is used in the stretch of sentence. }\end{array}$ \\
\hline $\begin{array}{l}\text { 5. Tragedy is a moment to unite } \\
\text { the nation. A large number of } \\
\text { Pakistani Sunnis were killed with } \\
\text { their Shia brothers in Quetta and } \\
\text { Karachi. More than } 50,000 \\
\text { Pakistanis from all backgrounds } \\
\text { have been killed since } 2007 \text {. The } \\
\text { News. March 7, } 2013\end{array}$ & $\begin{array}{l}\text { Spatial Proximization } \\
\text { Protagonists }=\mathrm{Np}=\text { Pakistani sunnis, shia brothers, } 50,000 \text { Pakistanis } \\
\text { Action= were killed, have been killed } \\
\text { Temporal Proximization } \\
\mathrm{T}=2013 \\
\mathrm{Tp}=2007 \\
\text { Narrative Proximization is invoked in the sentence as Antagonists, who is creating danger in } \\
\text { discourse is not overtly invoked in the sentence. The victims of actions are Pakistani nationals. }\end{array}$ \\
\hline $\begin{array}{l}\text { 6. The nation has played with } \\
\text { judicial and political issues. The } \\
\text { News. May } 14,2010\end{array}$ & $\begin{array}{l}\text { Spatial Proximization } \\
\text { Protagonists }=\text { judicial, political issues } \\
\text { Antagonists }=\text { the Nation } \\
\text { Action }=\mathrm{VP}=\text { has played } \\
\text { Temporal Proximization } \\
\mathrm{T}=2010 \\
\mathrm{~T} p=\text { present perfect tense }\end{array}$ \\
\hline
\end{tabular}




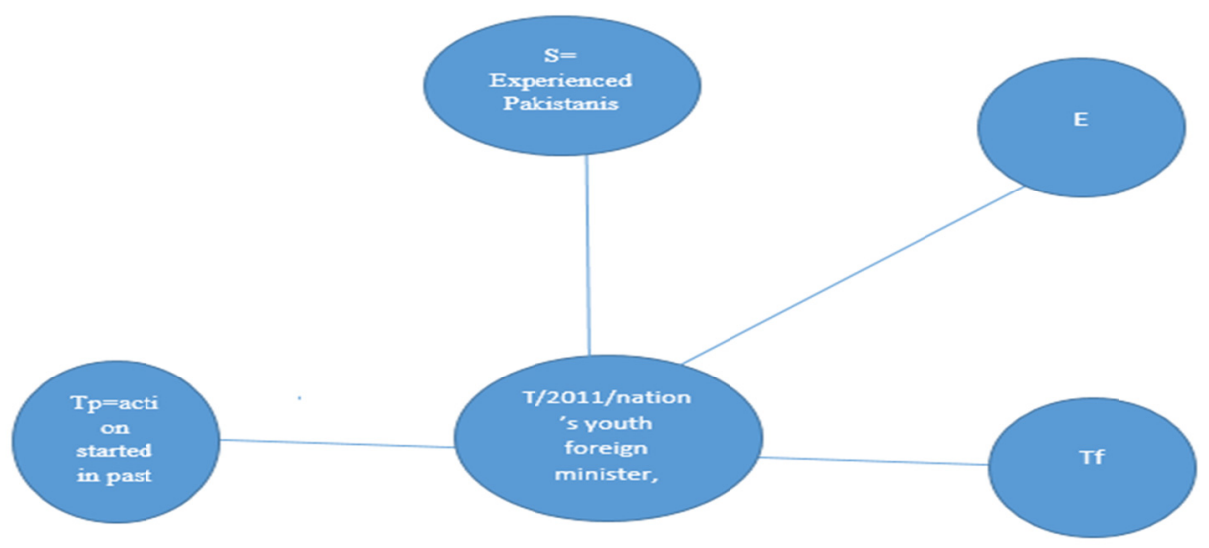

Figure 6. Deictic representation of Nation on DST model

Example 4 in Table 4 shows that antagonists who are experienced Pakistanis have carried out action which is presented on S axis. Protagonists are nation's youth and the foreign minister. The deictic center in Figure 6 opens a mental space by taking position on the role of experienced Pakistani who are a threat to the youth and are the antagonist whose actions are turning the youth into victims. The action continues from the past.

\subsubsection{Frequency of Deictic Pronouns}

The data analysis of the deixis 'us versus them' includes the personal pronouns 'I', we/they, us/them/ our/theirs. The data analysis of the frequencies in Table 5 shows that the highest frequency of occurrence is the deixis 'we, our and us'. This ideological manifestation of the deixis 'third person plural' shows that writers open the deictic center by including themselves. The 'we' pronoun includes both inclusive and exclusive (Appendix C). The use of 'we' depends how the deictic expression is used in the context to persuade or manipulate the readers. The lowest frequency of personal pronoun deixis is of 'I' which predicts that while taking any stance about ideology, the writers refer to the collective form in the form of we and our and I is less frequently used. The frequency of occurrence of the pronoun ' $\mathrm{I}$ ' is also less than 'you'. The writers do not directly refer to themselves, rather adopt a collective measure to address people and to link the events happened in the past. The frequency of "they" (Appendix D) is less than "we" in the text.

Table 5. Frequency of personal pronouns

\begin{tabular}{llll}
\hline No. & Personal pronoun & Frequency of occurrence & Normalized frequency* \\
\hline 1. & I & 18 & 10.32 \\
2. & You & 20 & 11.46 \\
3. & Us / we / our & $33+130+87=250$ & 143.43 \\
4. & They / them + their & $78+25+79=182$ & 104.42 \\
\hline
\end{tabular}

Note. ${ }^{*}$ Normalized frequency $=10,000$.

Table 5 shows the frequencies of spatial deixis which are used in the corpus. The ideological manifestation of 'national' "we" explains the positioning strategy employed by the writers to present their perspective on the national identity of Pakistan. The frequency of 'we' is the maximum while the frequency of ' $I$ ' is the minimum.

Table 6 shows the deixis of time: temporal deixis now/then. The Temporal deixis represents the link between past events with the present events. In this corpus, 'now' is the reference to any event happening at that particular time of the creation of the text which is related to Nation of Pakistan and War in Pakistan. 'Then' is the reference to any past events about the NATION and WAR.

Table 6. Frequency of Temporal Deixis

\begin{tabular}{llll}
\hline No. & Temporal & Frequency of occurrence & Normalized frequency* \\
\hline 1. & Now & 24 & 13.77 \\
2. & Then & 21 & 12.04 \\
\hline
\end{tabular}

Note. $*$ Normalized frequency $=10,000$. 
Table 6 shows that the temporal deixis of present and past are almost equivalent, as there is no big difference between the usages of "now"/"then" in the opinion articles. The normalized frequencies show the minimum difference between the two deixis, which is 1.73 (13.77-12.04). The writers of opinion articles, while discussing the present situation in Pakistan, kept referring to the past in the form of 'then'. There are many other ways to show the temporal deixis by direct reference to time and by using past tense as well. The representation of ideological "now" and "then" shows that the writers link the present situation in Pakistan with the past events and the reference to 'shared memories' by the nation links the nationals to each other.

\section{Conclusion}

The study revealed that the role of deixis is very significant in the representation of national identity discourse. The data analysis shows that deixis is used by the writers to conceptualize the different roles assigned to different political and non-political agents in the discourse. In this study, WAR and NATION frames were studied and the data was presented in terms of Discourse Space Theory (Hart, 2014). Events which are a part of shared memory were linked with present to conceptualize the negative image of the national identity of Pakistan. The opinion articles studied in this research presented a negative image of Pakistan by using deixis. The deictic expression is meaningful in this regard. The analysis shows that the process of victimization was carried out by the antagonists and as a result the protagonists suffer. The results show that the most occurring expressions were related to war on terror, and sectarian issues, ongoing war in Pakistan, tired nation, unlucky nation. Terrorists and political agents, are represented as antagonists. The role of temporal deixis was to link the events and the role of spatial deixis was to represent the person and place. Many references were given of historical personalities to create a link with current political leaders in Pakistan. Direct reference to the time in past represents a wider image formation of memory. The print media highlighted the negative perspectives regarding the national identity of Pakistan.

\section{References}

Anderson, B. R. O'G. (1991, 2006). Imagined communities: Reflections on the origin and spread of nationalism. London.

Baker, P. (2006). Using corpora in discourse analysis. A \& C Black.

Butler, J. (1999). Gender trouble. New York: Routledge.

Cap, P. (2006). Legitimisation in political discourse: A cross-disciplinary perspective on the modern US war rhetoric. Cambridge scholars publishing.

Chilton, P. (2004). Analyzing political discourse: Theory and practice. London: Routledge. https://doi.org/10.4324/9780203561218

Crystal, D. (2003). A dictionary of Linguistics and Phonetics (Vol. 5). Blackwell: Oxford.

Druckman, J. N. (2001). The implications of framing effects for citizen competence. Political Behavior, 23(3), 225-56. https://doi.org/10.1023/A:1015006907312

Fowler, R. (1991). Language in the news. Discourse and ideology in the British press. London: Routledge. https://doi.org/10.2307/415093

Gellner. (1965). Thought and change. London: Weidenfeld and Nicolson; Chicago: University of Chicago Press.

Guibernau, M. (2004). Anthony D. Smith on nations and national identity: a critical assessment. Nations and Nationalism, 10(1/2), 125-141. https://doi.org/10.1111/j.1354-5078.2004.00159.x

Hanks, W. F. (1992). The indexical ground of deictic reference. Cambridge: Oxford University Press

Hart, C. (2010). Critical discourse analysis and Cognitive science: New perspectives on immigration discourse. Basingstoke: Palgrave. https://doi.org/10.1057/9780230299009

Hart, C. (2014). Discourse, grammar and ideology: Functional and cognitive perspectives. Bloomsbury Publication.

Huang, Y. (2007). Pragmatics. Oxford University Press.

Herman, E, S., \& Chomsky, N. (1988). Manufacturing Consent: The political economy of the mass media. New York: Pantheon Books.

Langacker, R. W. (2008). Cognitive grammar: A basic introduction. Oxford University Press. https://doi.org/10.1093/acprof:oso/9780195331967.001.0001

McEnery, T., \& Wilson, T. (1996, 2001). Corpus Linguistics. Edinburgh: Edinburgh University Press. 
Smith, A. D. (1991). National Identity. University of Nevada Press.

Thompson, B. J. (1995). The media and modernity: A social theory of the media. Stanford: Stanford University.

VanDijk, T. A. (2008). Discourse and context. A socio-cognitive approach. Cambridge, UK: Cambridge University Press. https://doi.org/10.1017/CBO9780511481499

Wodak, R., \& Weiss, G. (2003). Critical discourse analysis. Theory and interdisciplinarity. Basingstoke: Palgrave Macmillan.

Yule, G. (1996). Pragmatics. Oxford: Oxford University Press.

\section{Appendix A}

\section{List of 15 Opinion Articles}

\begin{tabular}{|c|c|}
\hline Title of opinion article & Newspaper and Date of publication/DOIs \\
\hline The new Bonapartism & $\begin{array}{l}\text { The News August 10, } 2012 \\
\text { https://www.thenews.com.pk/print/88067-the-new-bonapartism }\end{array}$ \\
\hline Land grab at QAU—again & DAWN. December 24, 2016 https://www.dawn.com/news/1304068 \\
\hline Expecting miracles from jackasses & $\begin{array}{l}\text { The News, May 30, } 2008 \\
\text { https://www.thenews.com.pk/print/87105-expecting-miracles-from-jackasses }\end{array}$ \\
\hline For younger representation & DAWN, July 25, 2011 https://www.dawn.com/news/646725 \\
\hline The evil of our circumstances & $\begin{array}{l}\text { The News, October, } 12010 \\
\text { https://www.thenews.com.pk/print/87660-the-evil-of-our-circumstances }\end{array}$ \\
\hline A confused government & $\begin{array}{l}\text { The News, March 7, } 2013 \\
\text { https://www.thenews.com.pk/print/88179-a-confused-government }\end{array}$ \\
\hline Invest in education & $\begin{array}{l}\text { The News, February 10, } 2016 \\
\text { https://www.thenews.com.pk/print/97196-Invest-in-education }\end{array}$ \\
\hline Dangerous diagnosis - clear signs of exhaustion & $\begin{array}{l}\text { The News May 14, } 2010 \\
\text { https://www.thenews.com.pk/print/87576-dangerous-diagnosis-clear-signs-of-exhaustion }\end{array}$ \\
\hline The monster of terrorism & $\begin{array}{l}\text { The News January 26, } 2016 \\
\text { https://www.thenews.com.pk/print/93619-The-monster-of-terrorism }\end{array}$ \\
\hline At war with ourselves & DAWN. January 12, 2014 https://www.dawn.com/news/1080038/at-war-with-ourselves \\
\hline How TV dupes our public & DAWN, September 27, 2014 https://www.dawn.com/news/1134573 \\
\hline The terror of this war & DAWN, October 15, 2008 https://www.dawn.com/news/423656 \\
\hline Behold the molten rage of the honour armies & $\begin{array}{l}\text { The News March 14, } 2011 \\
\text { https://www.thenews.com.pk/print/87770-behold-the-molten-rage-of-the-honour-armies }\end{array}$ \\
\hline Bankruptcy of ideas & $\begin{array}{l}\text { The News, November 5, } 2010 \\
\text { https://www.thenews.com.pk/print/87683-bankruptcy-of-ideas } \\
\text { DAWN, November } 24,2007\end{array}$ \\
\hline Give us back our country & https://www.dawn.com/news/1073417/give-us-back-our-country \\
\hline
\end{tabular}




\section{Appendix B}

Total type /token ratio. Frequency of the token Pakistan

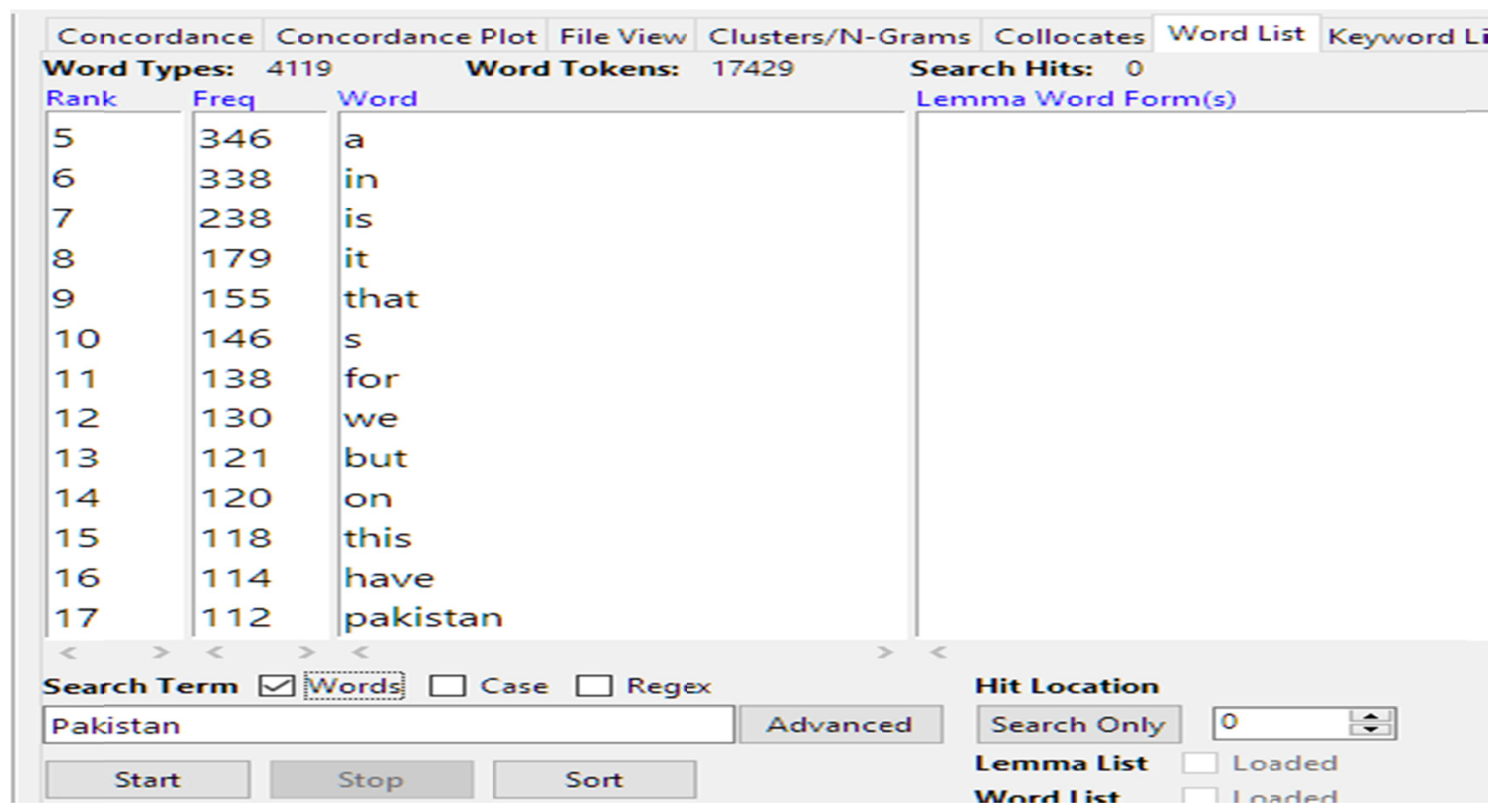

\section{Appendix C}

\section{Concordances of 'We'}

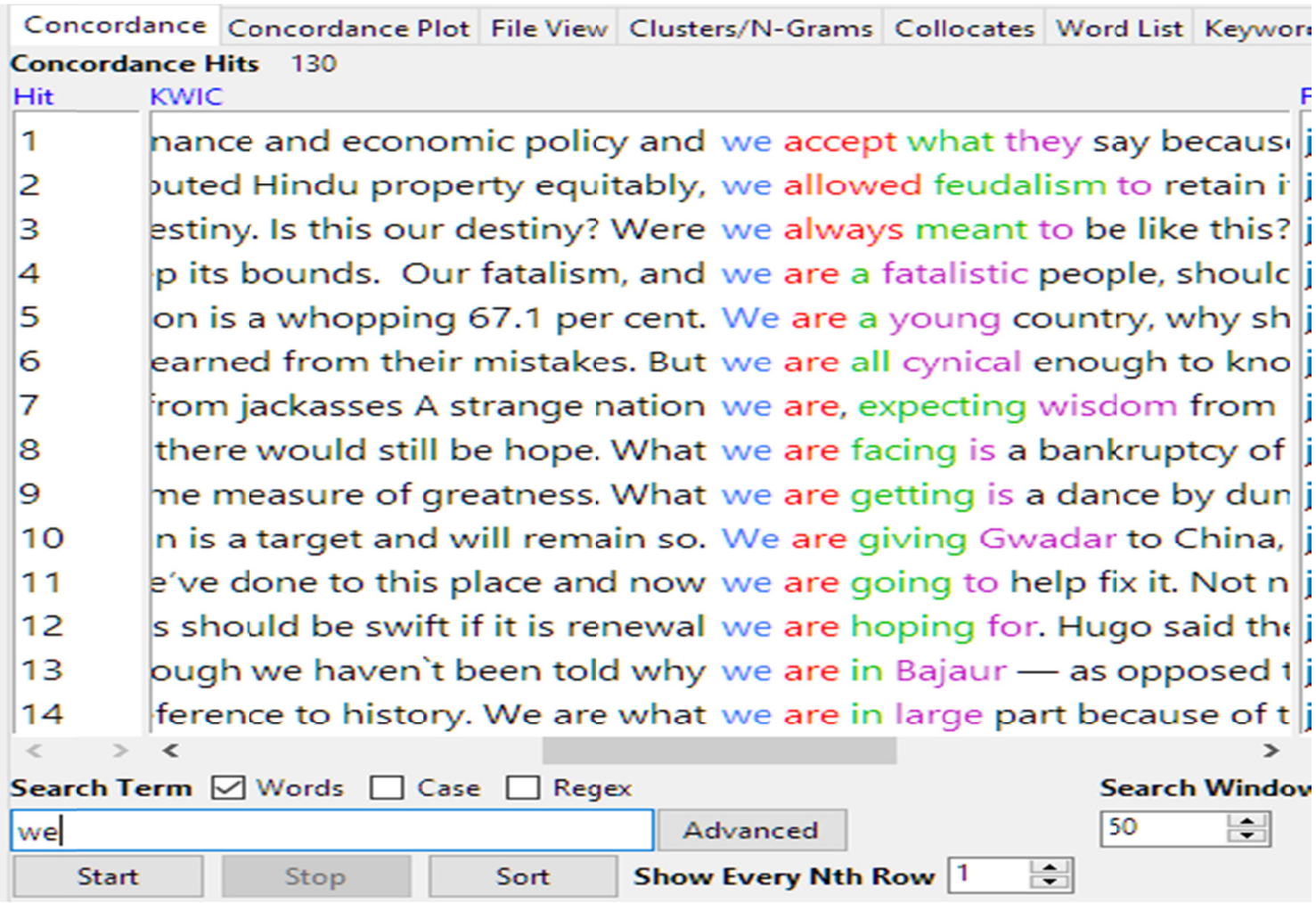




\section{Appendix D}

\section{Concordances of 'They'}

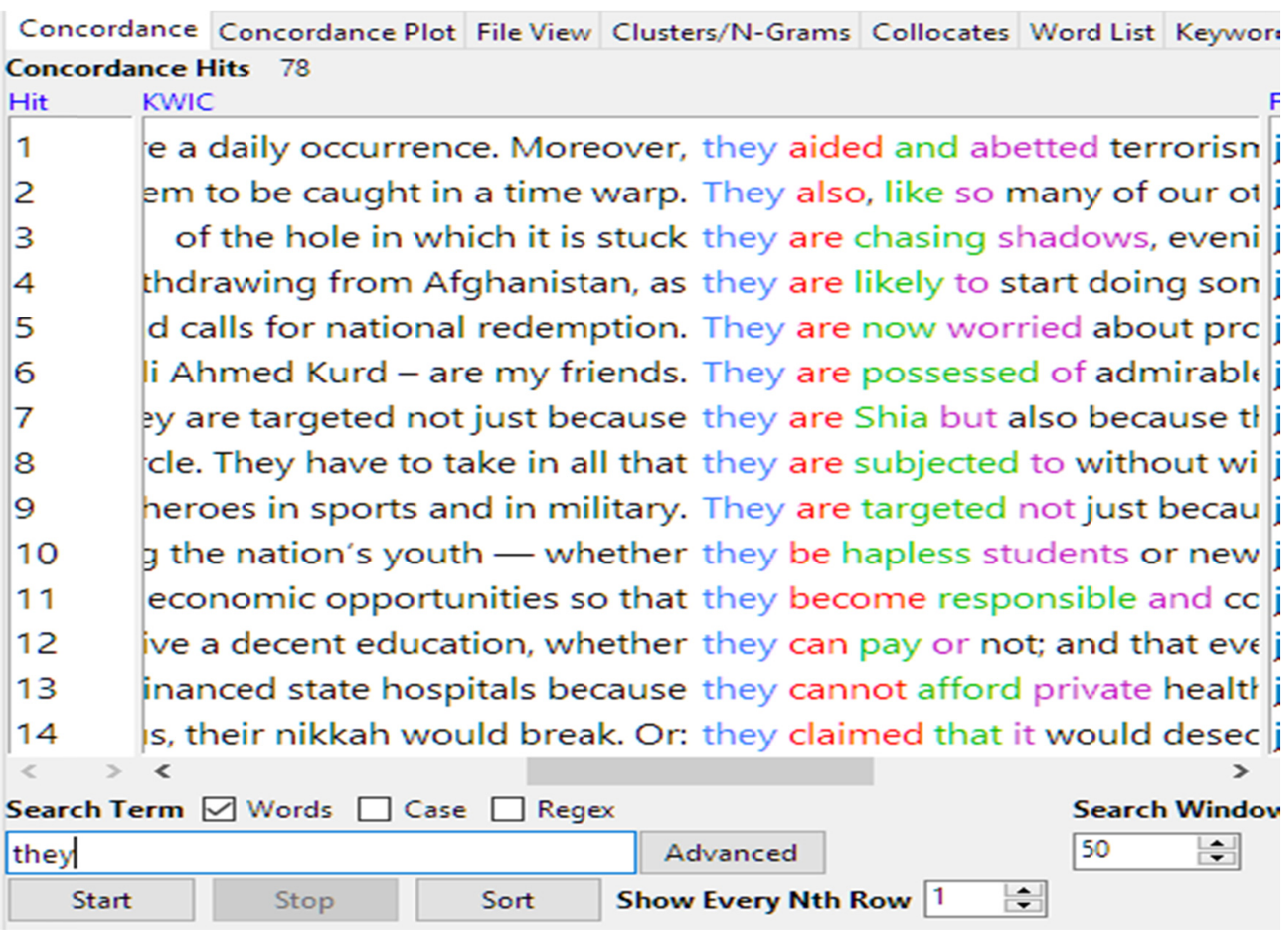

\section{Copyrights}

Copyright for this article is retained by the author(s), with first publication rights granted to the journal.

This is an open-access article distributed under the terms and conditions of the Creative Commons Attribution license (http://creativecommons.org/licenses/by/4.0/). 